\title{
GNAS NM_000516.5:C.679C>G
}

National Cancer Institute

\section{Source}

National Cancer Institute. GNAS NM 000516.5:C.679C>G. NCI Thesaurus. Code C146968.

A nucleotide substitution at position 679 of the coding sequence of the GNAS gene where cytosine has been mutated to guanine. 